\title{
Nuclear Receptor Corepressor 1
}

National Cancer Institute

\section{Source}

National Cancer Institute. Nuclear Receptor Corepressor 1. NCI Thesaurus. Code C18285.

Nuclear receptor corepressor 1 (2440 aa, $\sim 270 \mathrm{kDa}$ ) is encoded by the human NCOR1 gene. This protein is involved in both transcriptional repression and chromatin remodeling. 